\title{
http://dx.doi.org/10.18778/2080-8313.18.05
}

Wojciech Marciniak

(Uniwersytet Łódzki, Wydział Filozoficzno-Historyczny)

\section{UWAGI O KONTEKSTACH ZNACZENIOWYCH POJĘCIA „REPATRIACJA”Z ZSRR ORAZ O NABYWANIU Z JEJ TYTUŁU OBYWATELSTWA POLSKIEGO}

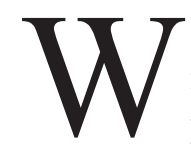

edług najbardziej rozpowszechnionej i zarazem najprostszej definicji termin „repatriacja” oznacza powrót do ojczyzny. Tymczasem próba jego głębszego zrozumienia wraz z uwarunkowaniami historycznymi, zwłaszcza tymi związanymi z dwudziestowiecznymi dziejami Polski, zobowiązuje do szerszego komentarza z uwzględnieniem kontekstów prawnych, politycznych, ideologicznych czy propagandowych. Najnowsza historia naszego kraju i jego mieszkańców naznaczona jest wieloma wzniosłymi, ale i tragicznymi wydarzeniami. Z punktu widzenia rozważań o repatriacji najistotniejsze wydają się fakty wiążące się z powstaniem niepodległej Polski w 1918 r., jej okupacją zapoczątkowaną atakami sąsiadów: zachodniego i wschodniego we wrześniu 1939 r., zmianą jej systemu politycznego i kształtu terytorialnego po II wojnie światowej oraz odzyskaniem suwerenności w 1989 r. Z pewnością niemały wpływ na ewolucję rozumienia czym w istocie były dwudziestowieczne ,powroty Polaków do ojczyzny” miały stosunki naszego kraju z bolszewicką Rosją i ZSRR. Dlatego też relacje Warszawy z Moskwą uczynię punktem odniesienia dla moich rozważań, które będą uwzględniały przede wszystkim formalno-prawną perspektywę rozpatrywania spraw repatriacji.

Wkrótce po wkroczeniu na arenę dziejową zjawiska masowych przyjazdów do Polski rodaków z różnych części świata, tj. po 1918 r., repatriacja została związana $\mathrm{z}$ zagadnieniem obywatelstwa polskiego ${ }^{1}$. Związek ten miał różne nasilenie w kolejnych dekadach i kształtowały go szczególne czynniki historyczne. Ustawa regulująca prawną przynależność państwową mieszkańców II Rzeczypospolitej została przyjęta 20 stycznia 1920 r. Wyszczególniała ona m.in. sposoby nabycia obywatelstwa polskiego poprzez: urodzenie, uprawnienie, uznanie, przysposobienie, zamążpójście, nadanie lub objęcie urzędu publicznego bądź przyjęcie

${ }^{1}$ Wśród nowszych publikacji poruszających w sposób syntetyczny tematykę repatriacji i przesiedleń w kontekście obywatelstwa polskiego warto przywołać opracowanie R. Wyszyńskiego z 2013 r. - R. Wyszyński, Przesiedlenia ludności polskiej z ZSRR w latach 1920-1960, „Studia Biura Analiz Sejmowych Kancelarii Sejmu” 2013, nr 2, s. 107-130. 
do służby wojskowej². Jak widać ówczesny polski ustawodawca nie przewidział trybu stania się obywatelem RP z tytułu repatriacji ${ }^{3}$. Warto jednak podkreślić, że intencją twórców ustawy było utworzenie masy obywateli nowego państwa, nie zaś mnożenie kategorii przywiązania prawnego do odrodzonej ojczyzny ${ }^{4}$.

Tymczasem 24 lutego 1921 r. w Rydze pomiędzy Polską a radziecką Rosją i Ukrainą został zawarty układ o repatriacji ${ }^{5}$. Dotyczył on przebywających na terytoriach jego stron ,zakładników, jeńców cywilnych, osób internowanych, jeńców wojennych, wygnańców, uchodźców i emigrantów". W porozumieniu wyjaśniono, kogo należy rozumieć pod wyszczególnionymi kategoriami potencjalnych repatriantów. I tak jeńcy cywilni i internowani to „obywatele" drugiej strony - znajdujący się pod strażą, w areszcie, pod nadzorem sądowym bądź administracyjnym, a także represjonowani za przestępstwa polityczne lub antypaństwowe (w tym także za działalność na rzecz strony przeciwnej w wojnie 1919-1920). Ponadto do tej grupy zaliczono osoby zatrzymane prewencyjnie oraz zakładników. Natomiast jeńcy wojenni to osoby ujęte przez armie walczących stron podczas działań zbrojnych. Z kolei wygnańcy i uchodźcy to ci, którzy przed 1 sierpnia 1914 r. zamieszkiwali terytorium jednej ze stron porozumienia i które w momencie jego podpisywania znajdowali się na obszarze strony przeciwnej (a od roku 1914 zostali przesiedleni lub sami opuścili swoje ojcowizny). Do tej kategorii włączono także byłych jeńców Wielkiej Wojny, a także rosyjskich i ukraińskich wojskowych przebywających w Polsce, ale nie w warunkach niewoli jenieckiej. Ostatnią grupą byli emigranci, czyli osoby, które przed 1 sierpnia 1915 r. w wyniku prześladowań politycznych, narodowościowych lub religijnych wyemigrowały na terytorium drugiej strony. Repatriacja wszystkich wyżej wymienionych kategorii ludności miała odbywać na zasadach dobrowolności. W protokole dodatkowym do porozumienia znalazł się zapis, że transfery ludnościowe nie będą uzależnione od poddania się przez zainteresowanych repatriacją procedurze opcji, tj. wyboru obywatelstwa. Zapisy o prawie opcji znalazły się jednak w postanowieniach układu pokojowego pomiędzy Polską a Rosją i Ukrainą z 18 marca 1921 r. Artykuł VI „traktatu ryskiego” odnosił się do osób, które były pełnoletnie i chwili

${ }^{2}$ Ustawa z 20 I 1920 r. o obywatelstwie Państwa Polskiego, Dziennik Ustaw 1920, nr 7, poz. 44.

${ }^{3}$ Por.: M. Kurenda, Polityka repatriacyjna Polski. Zarys ewolucji rozwiązań instytucjonalno-prawnych w latach 1918-1998 (ekspertyza wykonana na zlecenie Biura Studiów i Ekspertyz Kancelarii Sejmu RP z czerwca 1999 r.), http://biurose.sejm.gov.pl/teksty_pdf_99/e-188.pdf (dostęp z 1 XII 2016 r.), s. 7-8.

${ }^{4}$ Por.: W. Marciniak, Polskie interpretacje umowy z ZSRR z 6 lipca 1945 r.w kwestii obywatelstwa osób przebywajacych na terytoriach państw trzecich, „Echa Przeszłości” 2016, t. XVII, s. 219.

${ }_{5}$ Uktad o repatriacji zawarty między Rzeczpospolita Polska a Rosyjska Socjalistyczna Republika Rad i Ukraińska Socjalistyczna Republika Rad wraz z protokotem dodatkowym, [w:] Dokumenty i materiaty do historii stosunków polsko-radzieckich, t. III, kwiecień 1920-marzec 1921, [Warszawa 1964], s. 551-565.

${ }^{6}$ Określenia „obywatel” nie użyto w znaczeniu prawnym. Należy pamiętać, że wyszczególnione grupy ludności obywatelstwo jednej bądź drugiej strony miały dopiero nabyć. 
jego ratyfikacji znajdowały się na obszarze Rosji lub Ukrainy i spełniały warunki uzyskania obywatelstwa polskiego wyszczególnione w art. 2 ustawy z 20 stycznia 1920 r. (w punktach a i d), a mianowicie: byli zapisani (lub mieli do tego prawo) do ksiąg ludności stałej byłego Królestwa Polskiego bądź do gminy miejskiej lub wiejskiej lub też do jednej z organizacji stanowych na ziemiach byłego imperium rosyjskiego, które weszły w skład Polski. Takie osoby po poddaniu się opcji mogły zostać zaliczone w poczet polskich obywateli. Ponadto przejście tej procedury dotyczyło również mieszkańców Rosji i Ukrainy, którzy udowodnią, że byli potomkami uczestników walk o niepodległość Polski z lat 1830-1865 lub stałych mieszkańców I Rzeczypospolitej oraz zachowali łączność z polską kulturą. Oświadczenia o wyborze obywatelstwa zainteresowani powinni byli składać przed konsulem bądź innym uprawnionym przedstawicielem Polski ${ }^{7}$.

Przed II wojną światową repatrianci ze Wschodu nabywali zatem polskie obywatelstwo w drodze administracyjnego uznania na podstawie przepisów ustawy z 1920 r. II Rzeczpospolita kwalifikowała niemal wszystkie osoby przyjeżdżające do Polski z m.in. radzieckiej Rosji i Ukrainy (a potem z ZSRR) do kategorii repatriantów. Należy także podkreślić, że w konsekwencji tamtej repatriacji nikt nie odzyskiwał polskiego obywatelstwa, a je nabywał, gdyż polska państwowość wraz z jej współczesnym rozumieniem formalnej przynależności jej mieszkańców była nowym bytem prawnomiędzynarodowym, a wśród osób, które przyjechały do Polski na mocy polsko-rosyjsko-ukraińskiej umowy z lutego $1921 \mathrm{r}$. nie było już prawdopodobnie nikogo, kto był mieszkańcem Polski przedrozbiorowej. Uwzględniając ten fakt termin repatriacja w okolicznościach dwudziestolecia międzywojennego należałoby rozpatrywać zatem jako ,powrót na ziemie polskie" (w sensie te, które weszły w skład II RP) z oddalonych obszarów - np. z Rosji, Syberii, Ukrainy. Gdyby jednak uwzględnić czynnik zaistnienia na arenie międzynarodowej geopolitycznego i prawnego faktu powstania Rzeczypospolitej w 1918 r. i odnieść go do osób, które ,repatriowały się” z np. Kresów Wschodnich I RP (nazywanych po rozbiorach ,ziemiami zabranymi”) - w sensie obszarów, które nie weszły w skład Polski po wojnie z Rosją bolszewicką, wówczas repatriację rozumieć powinno się jako „przyjazd do Polski”. Uwzględniając kryterium terytorialne repatriacja dotyczyła osób, które bezpośrednio w wyniku działań wojennych z lat 1914-1920 opuściły obszary przyszłej II RP (i znalazły się na Wschodzie) albo od lat zamieszkiwały obszary, które nie znalazły się w jej granicach po traktacie ryskim (a które należały do Polski przed rozbiorami), bądź w okresie zaborów (lub ewentualnie wcześniej, choć biologia raczej to wykluczała) zostały zesłane, wyjechały lub w innych okolicznościach znalazły się w głębi Rosji (oraz ich potomków). Nietrudno zauważyć, że punktem odniesienia do obrania perspektywy pojmowania pojęcia „repatriacja” w II RP jest kwestia

${ }^{7}$ Tamże, s. 578-580. 
powstania/odrodzenia Polski oraz wiążąca się z nią konstrukcja prawna polskiego obywatelstwa. Jednak właściwego dla „repatriacji” określenia „powrót” w przypadku Polski przedwojennej nie powinno się łączyć z terminem nawiązującym do państwa (by do państwa powrócić, najpierw należało z niego wyjechać, a Polski jako bytu prawnego przecież nie było), ale z obszarami, które weszły w skład państwa, które dopiero co powstało. Inaczej mają się sprawy, gdy użyjemy słów w rodzaju „przyjazd”, „przesiedlenie”, czy „przybycie”. Wówczas logicznie możemy je łączyć z określeniami konstytutywnymi dla tej polskiej państwowości, która zaistniała na arenie dziejowej w 1918 r. ${ }^{8}$.

Los II Rzeczypospolitej i jej mieszkańców został przesądzony w tajnym protokole dołączonym do paktu Ribbentrop-Mołotow z 23 sierpnia 1939 r. Realizując postanowienia tego zbrodniczego układu Sowieci anektowali w latach 19391940 wschodnie obszary Polski, a przebywającej tam ludności narzucili wbrew prawu międzynarodowemu obywatelstwo ZSRR (przede wszystkim na podstawie dekretu Prezydium Rady Najwyższej ZSRR z 29 listopada 1939 r.). Ponadto ok. 320 tys. spośród nich zesłali w głąb swojego państwa w ramach czterech, masowych akcji deportacyjnych prowadzonych w latach 1940-1941. Kolejne rzesze obywateli II RP trafiały na „nieludzką ziemię” w okresie II wojny światowej jako m.in. jeńcy czy więźniowie (a także - choć w niewielkiej liczbie - jako dobrowolni pracownicy). W końcowej fazie działań zbrojnych i po ich zakończeniu w 1945 r. na Wschód, poza przedwojenną granicę z Polską, radzieckie władze bezpieczeństwa kierowały kolejne dziesiątki tysięcy osób polskiego pochodzenia. Fakt posiadania przez zdecydowaną większość tych wszystkich osób obywatelstwa ZSRR (bezprawnie i przymusowo narzuconego) miał brzemienne skutki dla spraw przesiedleńczo-repatriacyjnych w okresie powojennym, szczególnie w relacjach „ludowych” władz Polski ze wschodnim mocodawcą i patronem. W latach 1944-1957 Polska zawarła w sumie pięć umów międzynarodowych o interesującym nas charakterze. Ich stronami był ZSRR lub poszczególne jego republiki. Warto dodać, że Polska „lubelska” do wejścia w życie postanowień tzw. małej konstytucji z 1947 r. odwoływała się do ustawy zasadniczej z marca 1921 r. (co zostało wyrażone już w manifeście Polskiego Komitetu Wyzwolenia Narodowego z lipca 1944 r.), zaś w kwestii obywatelstwa aż do 1951 r. w mocy utrzymywała zapisy ustawy z $1920 \mathrm{r}^{9}$

W sankcjonowanym przez nowe władze państwowe nad Wisłą dyskursie publicznym wszelkie ruchy migracyjne Polaków ze Wschodu nazywane były

${ }^{8}$ O praktyce przyznawania polskiego obywatelstwa repatriantom ze Wschodu po I wojnie światowej patrz m.in. w: K. Zieliński, Kwestia obywatelstwa polskiego dla repatriantów, reemigrantów i uchodźców z Rosji w latach 1918-1922. Regulacje prawne a praktyka urzędnicza, „Dzieje Najnowsze" 2001, t. 4, s. 23-36.

${ }^{9}$ Więcej w temacie systemu, który został ukształtowany w Polsce powojennej zob. m.in. w: J. Wrona, System polityczny w Polsce w latach 1944-1948, „Pamięć i Sprawiedliwość” 2005, nr 2(8), s. 51-70. 
repatriacją. Usilnie forsowane hasła o „powrocie Polski na ziemie piastowskie" miały ścisły propagandowy związek z zasiedlaniem tych terenów ludnością przybyłą w nowe granice Polski m.in. ze obszarów wschodnich II RP, które oficjalnie nazywano „odstąpionymi ZSRR”.

Przesiedlenia z kresowych województw Polski przedwojennej, anektowanych przez Moskwę podczas wojny i ponownie zajętych przez Armię Czerwoną w 1944 r., były w okresie Polski „ludowej” błędnie nazywane repatriacją. Propaganda podporządkowanych Kremlowi władz w Warszawie głosiła tezę, że oto Polacy z Kresów „wracali do ojczyzny”, tj. w większości na „ziemie odzyskane”. Oba wyżej wymienione hasła nie znajdowały odbicia w rzeczywistości. Z repatriacją mielibyśmy do czynienia, gdyby te osoby faktycznie wcześniej z Polski wyjechały. Tymczasem „znalazły się” one poza krajem nie z powodu jego opuszczenia, ale w konsekwencji zmiany terytorialnej usankcjonowanej polsko-radziecką umową o granicy państwowej z 16 sierpnia 1945 r. ${ }^{10}$ (a wcześniej porozumieniem PKWN-ZSRR z 27 lipca 1944 r.). Nie mogły więc „powrócić” do ojczyzny, gdyż jej nie opuściły. Tak samo ludność kresowa nie „powracała” na „ziemie odzyskane”, gdyż wcześniej nigdy tam na stałe nie przebywała. Ponadto sam termin „ziemie odzyskane” (który znalazł się nawet we wstępie do konstytucji PRL z 1952 r.) jest oczywistym przekłamaniem. Do dzisiaj jednak funkcjonuje w polskiej historiografii poprzedzony zazwyczaj jedynie skrótem „tzw.”. Szkoda, że przez ponad dwie i pół dekady po odzyskaniu przez Polskę suwerenności nie utrwaliło się w dyskursie naukowym bardziej adekwatne określenie. Być może mógłby nim być termin ,ziemie przyłączone”. Jest on bowiem pozbawiony naleciałości propagandowych czy ideologicznych, a jednocześnie uwzględnia kontekst historyczny, w jakim obszary zachodnie i północno-wschodnie znalazły się w granicach państwa polskiego - są to przecież tereny przyłączone do Polski po II wojnie światowej.

Wtłoczenie wszystkich strumieni migracyjnych Polaków z ZSRR po 1944 r. do wspólnego pojęcia repatriacji miało sztuczny charakter. Było utrwalane nie tylko za pomocą narzędzi propagandowych, mających kształtować świadomość obywatela „ludowej” ojczyzny, w której nie miało być miejsca na pamięć o polskich Kresach Wschodnich, ale także poprzez nazwę instytucji zajmujących się przesiedleniami i osiedlaniem przybyszy z różnych stron świata. Jesienią $1944 \mathrm{r}$. PKWN powołał bowiem Państwowy Urząd Repatriacyjny oraz Urząd Głównego Pełnomocnika do Spraw Ewakuacji, który został potem przekształcony (1945 r.) w Generalnego Pełnomocnika Rządu do Spraw Repatriacji (w ramach którego

${ }^{10}$ Umowa została ratyfikowana dopiero 5 II 1946 r., co oznacza, że do tego czasu obszary na wschód od tzw. linii Curzona z formalnego punktu widzenia były „ziemiami polskimi” i tak można je nazywać. Ma to niebagatelne znaczenie dla opisywania losów osób represjonowanych, walczących w szeregach podziemia niepodległościowego oraz przesiedlanych. W 1996 r. jednoznacznie wypowiedział się w tej sprawie Trybunał Konstytucyjny. Dziennik Ustaw 1996, nr 63, poz. 304. 
funkcjonowały: Urząd do Spraw Repatriacji Obywateli Polskich z ZSRR i Urząd do Spraw Repatriacji Obywateli Polskich z Zachodu).

Podstawą prawną do przesiedleń (bo taka nazwa jest prawidłowa) ludności polskiej ze wschodnich województw II RP były trzy układy zawarte pomiędzy PKWN a rządami radzieckich republik Białorusi i Ukrainy oraz Litwy. Stało się to odpowiednio 9 i 22 września 1944 r., przy czym z każdym z tych państw ekipa Edwarda Osóbki-Morawskiego zawarła osobne, choć niemalże jednakowo brzmiące porozumienie. Umowy zezwalały na obustronne transfery ludnościowe, a w ich tytułach zaznaczono, że chodzi o „obywateli polskich”. W art. 1 układów doprecyzowano jednak, że ,przesiedleniu” podlegali Polacy i Żydzi - obywatele polscy do 17 września 1939 r., a zatem w chwili zawierania traktatów ich sygnatariusze uznawali ich za obywateli radzieckich. Po przyjeździe na terytorium powojennej Polski osoby te uzyskiwały obywatelstwo polskie z tytułu „repatriacji” na podstawie jedynej prawnej możliwości, jaką dawała w tamtych okolicznościach ustawa z $1920 \mathrm{r}$., tj. w drodze uznania. W istocie był to tryb quasi uznania, bowiem przybyłej ludności nie wyposażano w żadne aktów nadania obywatelstwa polskiego. Na zaświadczeniach PUR, które otrzymywali przyjezdni, widniała jednak adnotacja, że jego posiadacz był repatriantem. To wystarczało, by władze Polski uznawały go za swojego obywatela ${ }^{11}$.

Problem właściwego uregulowania statusu prawnego (obywatelstwa) ogółu ludności polskiej przebywającej w ZSRR - zarówno na anektowanych przez Sowietów obszarach II RP, jak i w głębi tego państwa - stanął na porządku dziennym prac administracji PKWN, a następnie Rządu Tymczasowego i Tymczasowego Rządu Jedności Narodowej. W październiku 1944 r. Biuro Prawne Prezydium PKWN w opinii autorstwa Michała Schuldenfreia wyraziło pogląd o konieczności przywracania polskiego obywatelstwa Polakom w Związku Radzieckim. Miało to kluczowe znaczenie chociażby przy stosowaniu postanowień amnestii, którą 10 sierpnia 1944 r. władze ZSRR wydały dla obywateli RP. Jedynym odstępstwem ze strony Kremla w zakresie stosowania w praktyce decyzji Prezydium Rady Najwyższej ZSRR z listopada 1939 r. była zgoda z czerwca i lipca 1944 r. wydana przez to gremium na opcję na rzecz Polski przez osoby zaangażowane w walkę z Niemcami (oraz ich rodziny). W praktyce krok ten nie wpłynął na sytuację prawną ogólnej masy Polaków w ZSRR. Ponadto z powodu uznawania przez Moskwę zdecydowanej większości naszych rodaków na terytorium radzieckim za własnych obywateli, sierpniowe postanowienie amnestyjne pozostało w zasadzie martwe ${ }^{12}$. W podobnym duchu wypowiadał się prof. Henryk Raabe - ambasador

${ }^{11}$ Przesiedlenie ludności polskiej z Kresów Wschodnich do Polski 1944-1947, wybór, opracowanie i redakcja dokumentów: S. Ciesielski, Warszawa 1999, s. 55-62.

${ }^{12} \mathrm{~W}$. Marciniak, Uwagi o genezie polsko-radzieckiej umowy repatriacyjnej z 6 lipca 1945 r., „Acta Universitatis Lodziensis. Folia Historica” 2013, nr 91, Studia i szkice z dziejów XX wieku, pod red. A. Głowackiego, s. 119-120. 
RP w ZSRR w latach 1945-1946, który m.in. w dwóch istotnych raportach z grudnia 1945 r. (raport „,wigilijny”) oraz marca 1946 r. (raport „,wielkanocny”) logicznie argumentował za interpretacją przynależności do polskiej (a nie radzieckiej) państwowości Polaków represjonowanych w ZSRR. Postulaty polskie (nawet jeśli były wysuwane przez władzę z nadania moskiewskiego) w większości były trafne i uzasadnione. Nie spotykały się jednak z akceptacją Sowietów, którzy sprawy repatriacyjno-przesiedleńcze dotyczące Polaków załatwiali według własnego scenariusza ${ }^{13}$.

6 lipca 1945 r. w Moskwie została podpisana czwarta umowa dotycząca migracji naszych rodaków ze Wschodu ${ }^{14}$. Jej zawarcie poprzedziło przekazywanie przez polską Ambasadę radzieckiemu resortowi spraw zagranicznych kolejnych propozycji, które do pewnego stopnia regulowałyby sprawy obywatelstwa Polaków w ZSRR i ułatwiałyby im przyjazd do ojczyzny. Były one jednak odrzucane przez Kreml. Lipcowe porozumienie zredagowane przez urzędników radzieckich stwarzało możliwości interpretacji jego zapisów na niekorzyść chcących powrócić do ojczyzny Polaków ${ }^{15}$.

Mimo że termin „repatriacja” zasadniczo pasował do treści tego nowego układu (o czym niżej), nie został w nim użyty ani razu. Zastąpiono go dość enigmatycznym sformułowaniem „ewakuacja” (zastosowanym zresztą wcześniej w przypadku „umów republikańskich”). Trudno jednoznacznie stwierdzić, dlaczego postąpiono w ten sposób. Być może wynikało to ze specyfiki nazewnictwa używanego przez Sowietów, bo to właśnie oni redagowali układy z Polską. Warto przy tym wspomnieć, że to określenie znalazło swoje zastosowanie także w nazwie instytucji, która została powołana do zrealizowania postanowień umowy z lipca $1945 \mathrm{r}$. Była to Polsko-Radziecka Komisja Mieszana do Spraw Ewakuacji.

Lipcowe porozumienie w pierwszej kolejności dotyczyło prawa do zmiany obywatelstwa (z radzieckiego na polskie), a dopiero potem powrotu do Polski. Zresztą w przypadku tego układu słowo powrót jest jak najbardziej adekwatne. Dotyczył on bowiem w znakomitej większości tych naszych rodaków, którzy zostali deportowani latach 1940-1941 w głąb ZSRR. Znaleźli się oni w obcym kraju, poza przedwojenną granicą polsko-radziecką, skąd na mocy umowy mogli wrócić do politycznej ojczyzny, choć w przeważającej liczbie już nie na ojcowizny. Nim jednak ich prawo do repatriacji mogło zostać urzeczywistnione musieli poddać się skomplikowanej, upokarzającej, a często także niemożliwej do przejścia procedurze opcji. Do wyjazdu z ZSRR uprawnieni byli tylko Polacy i Żydzi

${ }_{13}$ Tenże, Dwa raporty ambasadora Henryka Raabego o obywatelach polskich represjonowanych w ZSRR (1943-1946), „Wrocławskie Studia Wschodnie” 2016, t. 20, s. 167-178.

${ }_{14}$ Dokumenty i materiaty do historii stosunków polsko-radzieckich, $t$. VIII, styczeń 1944 - grudzień 1945, [Warszawa] 1974, s. 500-505.

${ }^{15}$ W. Marciniak, Uwagi o genezie..., s. 123-129. O realizacji układu zob. m.in. w: W.F. Marciniak, Powroty z Sybiru. Repatriacja obywateli polskich z głębi ZSRR w latach 1945-1947, [Łódź 2014]. 
- obywatele II RP według stanu z 17 września 1939 r. Z działania porozumienia wyłączono osoby jednostronnie uznane przez władze radzieckie za innej narodowości, np. Białorusinów lub Ukraińców, a także tych rodaków, którzy zamieszkiwali terytorium radzieckie jeszcze przed 1939 r. Opcja polegała na udowodnieniu przed komisją radziecką swojej przynależności do Polski przedwojennej za pomocą urzędowych dokumentów. Do czynności weryfikacyjnych nie dopuszczono żadnego oficjalnego przedstawiciela Polski - ani wysłannika Ambasady RP w Moskwie ani pełnomocnika Polsko-Radzieckiej Komisji Mieszanej do Spraw Ewakuacji (nie licząc członków Związku Patriotów Polskich, którzy jednak z punktu widzenia Sowietów także byli obywatelami ZSRR). Ponadto w listopadzie 1945 r. Prezydium Rady Najwyższej ZSRR wydało dekret, na mocy którego repatrianci z głębi tego kraju odzyskiwali obywatelstwo polskie dopiero z chwilą opuszczenia jego granic. Wszystko to oznaczało, że to do Sowietów należała ostateczna decyzja o tym, kto mógł odzyskać polskie obywatelstwo i repatriować się do Polski. Władze krajowe mogły jedynie już na miejscu czysto formalnie uznać repatriantów za obywateli polskich.

8 stycznia 1951 r. została uchwalona pierwsza po wojnie ustawa o obywatelstwie polskim. Przewidywała ona m.in., że za polskich obywateli będą uznawane osoby, które $\mathrm{z}$ dniem jej wejścia w życie mieszkały w Polsce, a wcześniej przybyły do niej jako repatrianci. Tą ustawą potwierdzono zatem nabycie obywatelstwa polskiego tych, którzy legitymowali się statusem repatrianta. Ponadto w przepisach odniesiono się do osób, które były obywatelami II RP (według stanu z 31 sierpnia $1939 \mathrm{r}^{16}$ ), ale przebywały stale poza Polską i w związku ze zmianą jej granic nabyły zgodnie z umową międzynarodową obywatelstwo innego państwa. Powyższa sytuacja dotyczyła oczywiście osób, które pozostały w ZSRR - czy to na obszarach Polski włączonych do tego kraju, czy też w jego głębi. Tym aktem Polska „ludowa” oficjalnie potwierdziła stanowisko Kremla: Polacy w ZSRR to obywatele radzieccy. O ile jeszcze w połowie latach czterdziestych XX w. „ludowe” władze nad Wisłą w dokumentach dyplomatycznych w kontekście repatriacji lub przesiedlenia nazywały ludność polską na Wschodzie obywatelami polskimi, to pod koniec tej dekady i w następnej już tego zaprzestawano. Ponadto w ustawie podkreślono, że obywatelami RP nie były osoby narodowości białoruskiej, estońskiej, litewskiej, łotewskiej, rosyjskiej i ukraińskiej, nawet jeśli przed wojną należały do polskiej państwowości ${ }^{17}$.

Mimo że ustawa bezpośrednio odnosiła się do spraw repatriacji, wciąż brakowało prawnej interpretacji tego pojęcia, natomiast ta sformułowana na użytek propagandy nie miała zastosowania w praktyce urzędowej. W maju $1951 \mathrm{r}$. Prezydium Rady Ministrów (PRM) skierowało do prezydiów rad narodowych oraz

${ }^{16}$ Zrezygnowano zatem z forsowania daty 17 IX 1939 r. jako krańcowego punktu odniesienia dla uznawania podmiotowości Polski na arenie międzynarodowej.

${ }^{17}$ Ustawa z 8 I 1951 r. o obywatelstwie polskim, Dziennik Ustaw 1951, $\mathrm{nr}$ 4, poz. 25. 
Biura Konsularnego MSZ projekt okólnika wyjaśniającego termin „,repatriant” z prośbą o wyrażenie opinii ${ }^{18}$. W dokumencie doprecyzowano te artykuły ustawy ze stycznia 1951 r., które dotyczyły repatriacji. Wskazano, że stanowi ona podstawę do nabycia obywatelstwa polskiego przez tych repatriantów, którzy w chwili repatriacji posiadali obywatelstwo obce, zaś warunkiem repatriacji osób nieposiadających polskiego obywatelstwa miało być ich polskie pochodzenie oraz ,wola przybycia do Polski Ludowej, jako swojej Ojczyzny, celem osiedlenia się”. Osoby zaliczane do tej kategorii przyjechały do kraju na podstawie zaświadczeń polskich urzędów zagranicznych lub zbiorczych wykazów masowych transportów, względnie legitymując się paszportami obcego państwa, z którym Polska nie zawarła porozumienia o repatriacji. Dalej wyjaśniono, że członkowie rodzin repatrianta o innej niż polska narodowości sami nie byli repatriantami w rozumieniu nowej ustawy, a polskie obywatelstwo mogły nabyć jedynie w drodze nadania przez Radę Państwa. Nie zmieniał tego nawet fakt posiadania przez nich zaświadczenia Państwowego Urzędu Repatriacyjnego lub polskich urzędów zagranicznych, ani nawet polskich paszportów. W okólniku znalazła się informacja, że w masie przesiedleńców i repatriantów (w tym także z ZSRR), która przybyła do Polski po II wojnie światowej, mogły znaleźć się osoby posiadające obce obywatelstwo, które ,wprowadziły w błąd polskie urzędy zagraniczne co do swego rzekomo polskiego pochodzenia i nie powinny były być repatriowane do Polski”. W razie wykrycia takiego przypadku należało odebrać tej osobie dokument repatriacyjny (za pokwitowaniem), uchylić wydane już poświadczenie obywatelstwa oraz skierować sprawę do właściwego organu rejestracji cudzoziemców ${ }^{19}$.

W sprawie definicji pojęcia ,repatriant” zaproponowanej przez PRM wypowiedziało się m.in. Biuro Konsularne MSZ. Okólnik został poddany krytyce ze względu na brak ścisłości. Chodziło o zastosowanie określenia „członkowie rodziny", które mogło być interpretowane zbyt szeroko. Tymczasem zdaniem Biura w kontekście nowej ustawy za członka rodziny powinno się uznawać jedynie współmałżonka (z pominięciem krewnych w linii prostej, bocznej, rodzeństwa oraz dzieci). W przypadku dziecka repatrianta - argumentował MSZ - wystarczy, żeby chociaż jedno z rodziców było polskiego pochodzenia, by także ono mogło być uznane za Polaka. W analogicznej sytuacji prawnej znajdowaliby się inni małoletni krewni repatrianta, jeśli będzie on ich wyłącznym ustawowym opiekunem, a zatem nabyłyby polskie obywatelstwo z mocy samego prawa. Biuro Konsularne zakwestionowało także podaną projekcie okólnika możliwość uzy-

18 Archiwum Ministerstwa Spraw Zagranicznych w Warszawie (dalej: AMSZ), zespół akt: Biuro Konsularne (dalej: BK), sygn. 20-41-503, Pismo M. Broniatowskiego (dyrektora Biura Spoleczno-Administracyjnego Prezydium Rady Ministrów) do Biura Konsularnego MSZ z 25 V 1951 r., k. 123.

${ }_{19}$ Tamże, Okólnik (projekt) M. Broniatowskiego do Prezydiów Wojewódzkich Rad Narodowych, Rad Narodowych Warszawy i Łodzi oraz prezydiów powiatowych, miejskich $i$ dzielnicowych rad narodowych z maja 1951 r., k. 124-124v. 
skiwania przez cudzoziemców paszportów polskich wydawanych przez urzędy konsularne RP (celem przybycia do Polski). Zdaniem MSZ taka procedura stała w sprzeczności z przepisami dotyczącymi wystawiania paszportów i praktyką polskich urzędów konsularnych (przedstawicielstwa nie wydawały wszak polskich paszportów osobom nieposiadającym polskiego obywatelstwa). Wskazane byłoby w tym wypadku zaznaczenie w okólniku, że nie chodziło o paszporty, a o zaświadczenia wydane przez polski urząd zagraniczny ${ }^{20}$.

Opinia Biura Konsularnego została wkrótce wsparta i uzupełniona przez Departament Prawno-Traktatowy MSZ, który zaproponował, by za członków rodziny repatrianta uznawać także inne osoby obcego pochodzenia pozostające z nim w stopniu pokrewieństwa lub powinowactwa. Departament zgłosił także zastrzeżenie do proponowanej przez Biuro Konsularne takiej redakcji okólnika, która wskazywałaby na analogiczne traktowanie dzieci repatrianta i innych małoletnich, nad którymi sprawował on prawną opiekę. Mogłoby to bowiem doprowadzić do kolizji z prawem macierzystym tych ostatnich. Departament sugerował zatem, by ograniczyć się do ogólnego stwierdzenia, że dzieci przybyłe z repatriantem do Polski i pozostające pod jego wyłączną opieką nabyły polskie obywatelstwo ${ }^{21}$.

18 lipca 1951 r. Biuro Konsularne skierowało do PRM końcową opinię w sprawie interpretacji pojęcia „repatriant”. Sformułowano w niej m.in. postulat, by w projektowanym okólniku znalazło się następujące stwierdzenie:

osoba pochodzenia innego niż polskie, przybyła do Polski jako małżonek repatrianta lub jako osoba pozostająca $\mathrm{z}$ repatriantem w pokrewieństwie lub powinowactwie i łącznie z nim osiedlająca się w Polsce, nawet i w tym wypadku gdy przybyła na podstawie zaświadczenia polskiego urzędu zagranicznego (dyplomatycznego, konsularnego, repatriacyjnego) lub uzyskała zaświadczenie wydane przez punkt przejęcia PUR, nie jest repatriantem w rozumieniu ustawy z dnia 8 stycznia $1951 \mathrm{r}$. i obywatelstwo polskie może nabyć jedynie w drodze nadania przez Radę Państwa. Małoletnie dzieci repatrianta, przybyłe wraz z nim do Polski lub nawet później na skutek poczynionych przezeń starań, nabywają obywatelstwo polskie z mocy samego prawa jeśli pozostają pod jego wyłączną opieką prawną.

Nowa redakcja okólnika - zdaniem MSZ - precyzyjniej określiła kto nie może być uznany za repatrianta i w związku $\mathrm{z}$ tym w jakim trybie przysługiwałoby mu nabycie obywatelstwa RP oraz prawną sytuację dzieci. W przypadku członków rodziny osoby powracającej w praktyce chodziło przecież przeważnie o małżonków, dzieci i innych krewnych lub powinowatych, którzy prowadzili z nim wspólne gospodarstwo domowe ${ }^{22}$.

${ }^{20}$ Tamże, Pismo Biura Konsularnego MSZ do Prezydium Rady Ministrów (Biura Społeczno-Administracyjnego) z lipca 1951 r., k. 127-128.

${ }^{21}$ Tamże, Pismo R. Łoca (dyrektora Departamentu Prawno-Traktatowego MSZ) do Biura Konsularnego MSZ z 18 VII 1951 r., k. 129.

${ }^{22}$ Tamże, Pismo Biura Konsularnego MSZ do Prezydium Rady Ministrów (Biura Społeczno-Administracyjnego) z 28 VII 1951 r., k. 130-130 verte. 
Wydaje się, że dezyderaty resortu spraw zagranicznych nie zostały przyjęte z zadowoleniem w PRM. Świadczy o tym chociażby brak informowania MSZ przez dłuższy czas o tym, czy zostały one uwzględnione i czy PRM zakończyło redakcję okólnika ${ }^{23}$. Dopiero w połowie listopada 1951 r. Mieczysław Broniatowski - dyrektor Biura Społeczno-Administracyjnego PRM - przesłał na al. Szucha swoją odpowiedź na postulaty wysuwane przez MSZ. Propozycja, by przepisy ustawy ze stycznia $1951 \mathrm{r}$. w sprawie dzieci repatriantów interpretować w ten sposób, że nabywały one obywatelstwo polskie z mocy samego prawa, nawet jeśli urodziły się w związkach mieszanych narodowościowo, była w jego ocenie ,zbyt wąska i niezgodna z intencją ustawy". W swojej argumentacji posłużył się jednak nie merytorycznym wywodem, a opinią Ministerstwa Bezpieczeństwa Publicznego (z którym był przecież zawodowo związany ${ }^{24}$ ), a MSZ poprosił o ,ponowne rozważenie tej kwestii i powiadomienie, czy podtrzymuje stanowisko zajęte w piśmie z dnia 28 lipca 1951 r."25.

W dołączonej do pisma Broniatowskiego krótkiej notatce zredagowanej w MBP (z 13 września 1951 r.), znalazła się jednak opinia do pewnego stopnia zgodna z postulatami MSZ. W piśmie dyrektor gabinetu ministra Stanisława Radkiewicza zauważył bowiem, że w projekcie okólnika PRM pominięto problem dzieci z małżeństw mieszanych, które przybyły do Polski wraz z rodzicami, z których tylko jeden opiekun stał się obywatelem polskim z tytułu repatriacji. „Zdaniem Ministerstwa należy kwestię tego rodzaju dzieci postawić i rozstrzygnąć w kierunku traktowania ich jako obywateli polskich" - napisano w opinii. W przypadku zagadnienia nielegalnej repatriacji (np. osób, co do których zachodziło podejrzenie, że zataiły swoje niepolskie pochodzenie) resort zauważył, że istnieje prawdopodobieństwo, że tą drogą dostała się do Polski większa grupa osób z ZSRR - np. poprzez bezprawne powołanie się na polskie obywatelstwo sprzed wybuchu wojny. Autor dokumentu postulował zatem rozpoczęcie współpracy pomiędzy terenowymi urzędami bezpieczeństwa a radami narodowymi w zakresie identyfikowania „osób niepożądanych w charakterze obywateli polskich”26.

Wkrótce resort spraw zagranicznych (Biuro Konsularne i Departament Prawno-Traktatowy) przychylił się do propozycji wysuwanych przez MBP, a 19 lutego 1952 r. gotowy już był okólnik PRM skierowany do rad narodowych w sprawie interpretacji pojęcia ,repatriant”. Wskazano w nim, że władze polskie na mocy ustawy z 8 stycznia 1951 r. stwierdzały obywatelstwo polskie osobom,

${ }^{23}$ Tamże, Pismo L. Szybaka (dyrektora Biura Konsularnego MSZ) do Prezydium Rady Ministrów (Biura Społeczno-Administracyjnego) z 19 X 1951 r., k. 131.

${ }^{24}$ Zob.: K. Lesiakowski, Mieczysław Broniatowski - meandry kariery „dąbrowszczaka” w PRL, „Przegląd Nauk Historycznych” 2015, nr 1, s. 107-131.

${ }^{25}$ AMSZ, BK, sygn. 20-41-503, Pismo M. Broniatowskiego do Biura Konsularnego MSZ z 16 XI 1951 r., k. 132.

${ }^{26}$ Tamże, Pismo dyrektora gabinetu ministra bezpieczeństwa publicznego do M. Broniatowskiego z 13 IX 1951 r., k. 133. 
które w chwili repatriacji posiadały obywatelstwo obce, a warunkiem ich repatriacji było polskie pochodzenie oraz „chęć przybycia do Polski Ludowej jako swojej ojczyzny z celem osiedlenia się". W okólniku znalazły się zapisy o trybie powrotów na podstawie zaświadczeń placówek zagranicznych, list transportów zbiorowych, paszportów obcych państw (po uprzednim ustaleniu przez polskie służby ich polskiego pochodzenia i woli przyjazdu do kraju w celu osiedlenia się). Współmałżonek repatrianta oraz inni jego krewni o niepolskiej narodowości mieli nie być uznawani za repatriantów i to bez względu na posiadane przez nich zaświadczenia urzędu zagranicznego lub PUR-u. Ponadto dziecko repatrianta nabywało obywatelstwo polskie z mocy samego prawa ${ }^{27}$.

Okólnik z lutego 1952 r. - mimo pewnych zastrzeżeń ze strony MSZ - stał się wytyczną w zakresie interpretacji pojęcia „repatriant” przede wszystkim w odniesieniu do spraw obywatelstwa polskiego. Wkrótce został rozesłany do władz terenowych oraz placówek zagranicznych. W kwestii migracji ze Wschodu władze Polski „ludowej” nie czyniły zatem rozróżnienia w zakresie tego, skąd przyjeżdżała dana osoba (ze wschodnich województw II RP czy z głębi ZSRR), nie wchodziły w niuanse historyczne, geograficzne czy semantyczne. Repatriacja oznaczała zatem przyjazd do Polski i nabycie obywatelstwa polskiego, czy precyzyjniej - automatyczne stwierdzenie tego obywatelstwa przez władze.

25 marca 1957 r. Polska podpisała ostatnią umowę o repatriacji ze Związkiem Radzieckim. Jej celem miało być - jak to wyrażono we wstępie - dokończenie procesu repatriacji ludności polskiej, która nie skorzystała z dotąd zawartych porozumień ${ }^{28}$. Układ dotyczył osób narodowości polskiej i żydowskiej - obywateli polskich do 17 września 1939 r., a także dzieci urodzonych po tym terminie (o ile nie posiadały one w ZSRR bliższych krewnych, którzy mogliby się nimi zaopiekować). Wraz z repatriantem do Polski mogli wyjechać także: jego współmałżonek, potomkowie i rodzice, nawet jeśli osoby te nie były polskiej (lub żydowskiej) narodowości i nie posiadały obywatelstwa II RP. Pod względem terytorialnym porozumienie dotyczyło formalnie wszystkich republik radzieckich. Zainteresowani wyjazdem do Polski mogli składać do urzędów milicji oświadczenia o zamiarze repatriowania się wraz z dokumentacją potwierdzającą polską narodowość i obywatelstwo II RP. Repatriacja miała w myśl tego układu odbywać się $\mathrm{w}$ trybie indywidualnym na podstawie zaświadczeń wydawanych przez milicję. Art. 10 umowy stwierdzał, że repatrianci przestawali być obywatelami ZSRR z chwilą opuszczenia granic tego kraju, a stawali się obywatelami polskimi po przybyciu na terytorium PRL. Towarzyszący im członkowie rodzin, którzy nie byli polskiej (lub żydowskiej) narodowości - w zależności od wyrażonego

${ }^{27}$ Tamże, Okólnik Prezydium Rady Ministrów z 19 II 1952 r. wyjaśniający pojęcie „repatriant” $w$ świetle ustawy o obywatelstwie polskim z 8 I 1951 r., k. 139-139 verte.

${ }^{28} \mathrm{O}$ przesiedleniach odbywających się na podstawie tego układu patrz szeroko w: M. Ruchniewicz, Repatriacja ludności polskiej z ZSRR w latach 1955-59, Warszawa 2000. 
życzenia, mogli pozostać ,poddanymi” radzieckimi lub nabyć polskie obywatelstwo. Spod działania umowy wyłączono osoby już przesiedlone bądź repatriowane (według terminologii użytej w tym dokumencie: „ewakuowane”) na mocy układów „ludowej” Polski z ZSRR z lat 1944-194529.

Z punktu widzenia przepisów ustawy z $1951 \mathrm{r}$. i umowy z 1957 r. repatriacja z ZSRR oznaczała przyjazd do Polski osób do tego uprawnionych i nabycie obywatelstwa polskiego z jej tytułu z mocy samego prawa. Władze w Warszawie po raz kolejny nie czyniły rozróżnienia na obszary, z których przybywała do PRL polska ludność. ZSRR był bowiem traktowany po prostu jako państwo, z którego „powracali” Polacy. Tymczasem w tym przypadku za repatriację należałoby uważać jedynie przyjazdy z głębi tego kraju. Rzeczywistymi repatriantami byliby zatem np. byli łagiernicy i więźniowie (obywatele II RP), którzy do radzieckich miejsc odosobnienia np. na Syberii czy w Kazachstanie trafili po 1944 r. (lub nawet wcześniej). Tymczasem w fali migracyjnej odbywającej się na mocy umowy z marca 1957 r. zdecydowaną większość stanowili mieszkańcy (i ich potomkowie) wschodnich województw II RP, które po II wojnie światowej znalazły się w granicach ZSRR. Oni jednak powinni być nazywani np. przesiedleńcami, bowiem do Polski ,jedynie” przyjeżdżali. Z uwagi na to, że Polska powojenna zasadniczo nie była nowym zjawiskiem geopolitycznym i prawnomiędzynarodowym, a kontynuowała (przynajmniej deklaratywnie) państwowość II RP, w przypadku migracji z drugiej połowy lat 50. XX w. z ZSRR nie możemy mówić o powrotach na ziemie polskie (tak jak w kwestii repatriacji przedwojennej), a o przybywaniu do Polski w jej nowych granicach.

Wkrótce po zakończeniu przesiedleń z lat 1955-1959 weszła w życie druga po wojnie ustawa dotycząca obywatelstwa polskiego. Przyjęto ją 15 lutego 1962 r. Zawarto w niej regulacje dotyczące obywatelstwa polskiego przez repatriantów. Na jej mocy uznawano, że nabywają oni polskie obywatelstwo z mocy samego prawa, zaś repatriantem jest:

cudzoziemiec narodowości polskiej lub pochodzenia polskiego, który przybył do Polski z zamiarem osiedlenia się na stałe, uzyskując na to zezwolenie właściwego organu polskiego.

Ustawa odnosiła się także do dzieci i wychowanków repatriantów, które automatycznie otrzymywały obywatelstwo polskie. Jednak w przypadku, gdy tylko jeden rodzic (lub opiekun) uzyskał status repatrianta, wówczas drugi powinien był wyrazić pisemną zgodę na nabycie przez potomka wychowanka obywatelstwa PRL ${ }^{30}$.

${ }^{29}$ Umowa między Rządem Polskiej Rzeczypospolitej Ludowej a Rządem Zwiąku Socjalistycznych Republik Radzieckich w sprawie terminu i trybu dalszej repatriacji z ZSRR osób narodowości polskiej z 25 III 1957 r., Dziennik Ustaw 1957, nr 47, poz. 222.

${ }^{30}$ Ustawa z 15 II 1962 r. o obywatelstwie polskim (tekst ogłoszony), Dziennik Ustaw 1962, nr 10, poz. 49 . 
Ustawa z 1962 r. nie wnosiła wiele nowego w zakresie interpretacji pojęcia „repatriant”. Przez kolejne dekady określała jednak relacje zachodzące pomiędzy zjawiskiem repatriacji a obywatelstwem Polski „ludowej”. Przemiany polityczne w naszym kraju z końca lat 80 . XX w. skutkowały m.in. zmianą nastawienia władz w Warszawie do spraw Polaków wciąż licznie jeszcze zamieszkujących byłe republiki radzieckie. Ustawa z 9 listopada $2000 \mathrm{r}$. wprowadziła nowe rozumienie zagadnienia repatriacji ze Wschodu. Jej nowelizacja z kwietnia $2017 \mathrm{r}$. obszernie wyjaśniła intencje państwa polskiego, które podejmuje kroki w kierunku umożliwienia rodakom przyjazdu do Rzeczpospolitej. Należą do nich poczucie powinności wobec Polaków na Wschodzie, którzy - mimo trudnych okoliczności politycznych - czynili wysiłki dla zachowania własnej tożsamości. Prawo do repatriacji jest zatem w pewnym sensie zadośćuczynieniem za krzywdy popełnione przez obce, zaborcze państwo. W znacznie rozszerzonym wstępie znowelizowanego aktu wyraźnie zaakcentowano konteksty historyczne - przede wszystkim podkreślono, że Polacy na Wschodzie w większości znaleźli się wbrew własnej woli, bo w wyniku represji. Ustawa z 2000 r. dotyczy jednak przeważnie potomków tych naszych rodaków, którzy przede wszystkim w skutek radzieckich deportacji zostali zmuszeni do zamieszkania z dala od ojczyzny i stron rodzinnych. Współczesnymi repatriantami nazywamy zatem w większości dzieci i wnuki tych, którzy faktycznymi repatriantami stać się nie zdołali lub już nie zdążyli ${ }^{31}$.

Wojciech Marciniak

\section{SOME REMARKS ON THE CONTEXTS OF MEANING OF THE TERM „REPATRIATION” FROM THE USSR AND THE RIGHT THAT IT GAVE TO POLISH CITIZENSHIP}

\footnotetext{
$\mathrm{T}$ he article shows the questions of repatriation and citizenship in Polish-Soviet relations. Not all of Polish migrations from the USSR in 20th century could be recognized as repatriation. That is why author categorizes different migrations as ,repatriation” or „resettlement” according to legal and historical issues. The article explains the relation between the terms ,repatriation” and „Polish citizen” in different periods of contemporary Polish history.
}

Słowa kluczowe: repatriacja, deportacja, przesiedlenie, zesłanie

Keywords: repatriation, deportation, resettlement, exile

${ }^{31}$ Ustawa z 9 II 2000 r. o repatriacji, Dziennik Ustaw 2000, nr 106, poz. 1118. 


\section{BIBLIOGRAFIA}

\section{Źródła archiwalne:}

Archiwum Ministerstwa Spraw Zagranicznych w Warszawie

Biuro Konsularne.

\section{Druki urzędowe:}

Dziennik Ustaw 1920, 1951, 1957, 1962, 1996, 2000.

\section{Źródła publikowane:}

Dokumenty i materiały do historii stosunków polsko-radzieckich, t. III, kwiecień 1920-marzec 1921, [Warszawa 1964].

Dokumenty i materialy do historii stosunków polsko-radzieckich, $t$. VIII, styczeń 1944 - grudzień 1945, [Warszawa] 1974.

Przesiedlenie ludności polskiej z Kresów Wschodnich do Polski 1944-1947, wybór, opracowanie i redakcja dokumentów: S. Ciesielski, Warszawa 1999.

\section{Opracowania:}

Kurenda M., Polityka repatriacyjna Polski. Zarys ewolucji rozwiąań instytucjonalno-prawnych $w$ latach 1918-1998 (ekspertyza wykonana na zlecenie Biura Studiów i Ekspertyz Kancelarii Sejmu RP z czerwca 1999 r. - http://biurose.sejm.gov.pl/teksty_pdf_99/e-188.pdf).

Lesiakowski K., Mieczysław Broniatowski - meandry kariery „dąbrowszczaka” w PRL, „Przegląd Nauk Historycznych" 2015, nr 1.

Marciniak W., Dwa raporty ambasadora Henryka Raabego o obywatelach polskich represjonowanych w ZSRR (1943-1946), „Wrocławskie Studia Wschodnie”2016, t. 20.

Marciniak W., Polskie interpretacje umowy z ZSRR z 6 lipca 1945 r. w kwestii obywatelstwa osób przebywających na terytoriach państw trzecich, „Echa Przeszłości” 2016, t. XVII.

Marciniak W., Powroty z Sybiru. Repatriacja obywateli polskich z głębi ZSRR w latach 1945-1947, [Łódź 2014].

Marciniak W., Uwagi o genezie polsko-radzieckiej umowy repatriacyjnej z 6 lipca 1945 r., „Acta Universitatis Lodziensis. Folia Historica” 2013, nr 91, Studia i szkice z dziejów XX wieku, pod red. A. Głowackiego.

Ruchniewicz M., Repatriacja ludności polskiej z ZSRR w latach 1955-59, Warszawa 2000.

Wrona J., System polityczny w Polsce w latach 1944-1948, „Pamięć i Sprawiedliwość” 2005, nr 2 (8).

Wyszyński R., Przesiedlenia ludności polskiej z ZSRR w latach 1920-1960, „Studia Biura Analiz Sejmowych Kancelarii Sejmu”2013, nr 2.

Zieliński K., Kwestia obywatelstwa polskiego dla repatriantów, reemigrantów i uchodźców z Rosji w latach 1918-1922. Regulacje prawne a praktyka urzędnicza, „Dzieje Najnowsze” 2001, t. 4. 